\title{
In-vitro Anti-Oxidant Property of Vallarai (Centella asiatica) cultivated by conventional and traditional Methods
}

\author{
Research Article
}

Indhu P M1 ${ }^{*}$, Sivakkumar $\mathbf{S}^{2}$, Meenakumari $\mathbf{R}^{3}$

1. PG Scholar, 2. Associate Professor, Department of Gunapadam, National institute of Siddha, Ministry of AYUSH, Government of India, Chennai 3. Professor/Director, National institute of Siddha, Ministry of AYUSH, Government of India, Chennai.

\begin{abstract}
In ancient times, Siddhars have been described and also used the traditional methods to cultivate the antioxidant herbs for rejuvenation purpose and also they are listed some plants as anti-oxidant herbs. They were used Semicarpus anacardium manure for cultivation of anti-oxidant plants. In Siddha, these anti-oxidant herbs are mentioned as Kayakarpam (Rejuvenation therapy). Most of the Non Communicable Diseases (NCD) are caused by oxidative stress. These anti-oxidant herbs are helps to reduce oxidative stress and prevent the incidence of NCDs. Centella asiatica (Vallarai) is one of the Kayakarpa medicinal plants. The traditional cultivation method for Kayakarpa herbs are also described in Siddha especially for Centella asiatica (Vallarai). Therefore, this study was aimed to validate the in-vitro anti-oxidant property of Vallarai cultivated by conventional (sample A) and traditional methods (sample B). The study samples were screened for anti-oxidant activity by DPPH assay, Nitric Oxide radical scavenging assay, ABTS assay and $\mathrm{H}_{2} \mathrm{O}_{2}$ radical scavenging assay and the $\mathrm{IC}_{50}$ value of the study drug, sample-A was $88.6 \pm 8.536(\mu \mathrm{g} / \mathrm{ml}), 183 \pm 15.55(\mu \mathrm{g} / \mathrm{ml}), 78.92 \pm 8.43(\mu \mathrm{g} / \mathrm{ml})$ and $183 \pm 11.64(\mu \mathrm{g} / \mathrm{ml})$ whereas sample- B was $57.06 \pm 1.221(\mu \mathrm{g} / \mathrm{ml}) ; 145.1 \pm 13.12(\mu \mathrm{g} / \mathrm{ml}) ; 96.45 \pm 3.966(\mu \mathrm{g} / \mathrm{ml})$ and $132.3 \pm 18.71(\mu \mathrm{g} / \mathrm{ml})$ respectively. This study results revealed that, both samples are possessing anti-oxidant property and sample B have greater scavenging activity compared to sample A. Hence, The Traditional method can be adopted for cultivation of antioxidant herbs, which helps to retain the active components and enhances the anti-oxidant potency of medicinal herbs.
\end{abstract}

Key Words: Kayakarpam, Anti-oxidant, Centella asiatica, Traditional cultivation method.

\section{Introduction}

Most of the Non Communicable Diseases (NCD) are caused by oxidative stress, inflammation and mitochondrial alterations. The anti-oxidant herbs or substances are help to reduce oxidative stress and prevent the NCDs like cardiovascular diseases, neurodegenerative diseases, cancer, diabetes and obesity etc. (1). Natural resources are having rich amount of anti-oxidant property. It act as a radical scavengers and helps in rejuvenation therapy. In Siddha, anti-oxidants are mentioned as Kayakarpam (2) (Rejuvenation therapy). In ancient times, Sage Siddhars have been listed some anti-oxidant herbs and also they described the traditional cultivation methods for rejuvenation purpose by using Semicarpus anacardium manure for cultivation (3). Siddhars used the Kayakarpam for the long living through preventing the diseases and treating the acquired diseases. Thirumoolar stated that in

* Corresponding Author:

Indhu P M

PG scholar,

Department of Gunapadam,

National institute of Siddha, Ministry of AYUSH,

Chennai - 600047. India

Email Id: drindhu2696@gmail.com
Thirumanthiram, the Kayakarpam protects the body and it acts as anti-oxidants which reduce the oxidative stress, cell damage and prevents aging by scavenging the free radicals.

Free radicals and reactive oxygen specious (ROS) are capable of damaging the important macromolecules like proteins, lipids etc. and leading to cell damage and disruption of homeostasis. Free radicals involve in the development of cancer, heart diseases and also aging. Oxidative stress is simply the elevation of free radicals found in cells that accumulate to higher than normal levels. Excessive oxidative stress damages cells and tissues, specifically mitochondria, cell membranes, DNA, proteins, and lipids (4). Oxidative stress takes place naturally and plays an important role in process of aging. Antioxidants prevent free radical induced tissue damage by preventing the formation as well as accumulation of radicals, scavenging them, or by promoting their decomposition and impede the progress of chronic diseases (5). The usage of anti-oxidant was emerging in the global market as anti-aging or rejuvenators in the form of face creams, body lotions and hair oils etc. But in ancient times Siddhars have been practiced the anti-oxidant herbs, rejuvenating activities like Yogam, Pranayamam in dayto-day life. Centella asiatica (Vallarai) is one of the Kayakarpa medicinal plants. The traditional cultivation method for Kayakarpa herbs are also described in 
Siddha (3) especially for Centella asiatica (Vallarai). Commonly people are using this plant for rejuvenation and to enhance the memory (Brain Booster) (6).

Centella asiatica (L.) Urban, a tropical medicinal plant belonging to the family Apiaceae, is widely distributed in many parts of the world especially in Asian countries such as India, China, Nepal, and other Southeast Asia countries including Malaysia and Indonesia. The plant can also be found in Australia, South Africa, the United States, and Europe (7). Major phytochemical present in Centella asiatica (Vallarai) are triterpenoid saponins, madecassoside, asiaticoside, asiatic acid, madecassic acid and minor phytochemicals are asiaticoside $\mathrm{B}$, brahminoside, brahmoside, centelloside, indcentelloside, thankuniside, isothankuniside, brahmic acid, isobrahmic acid, betulic acid, centic acid and centoic acid (8).

Centella asiatica has astringent, bitter and sweet taste, coolant potency and which is indicated for gastric ulcer, diarrhoeal diseases, elephantiasis, etc. (6) and used for the preparation of Vallarai Nei (9), Vallarai ennai (6). It is also used in insomnia, cardiac debility, epilepsy, laryngitis, asthma, bronchitis, hiccough, abdominal disorders, leprosy, strangury and fever. It has been found to be useful in diseases of skin, nerves and blood. Leaves are useful in abdominal disorders due to dysentery in children. They are also used as tonic and for improving memory, useful in syphilitic skin diseases both internally and externally (10). According to Siddha Materia medica Vallarai has Alterative, Tonic, Diuretic, Stimulant, Emmenagogue (6), and scientifically it was proved for its cardio protective effect (11), neuroprotection and cognitive enhancement action (12), anti-hyperglycemic activity (13), anti-cancer and antioxidant activity (14).

The study was aimed to validate the in-vitro anti-oxidant property of Centella asiatica cultivated by conventional and traditional methods. So that, this type of study may help to promote the traditional methods of cultivation for Kayakarpa medicinal plants.

\section{Materials and Methods}

The study samples were collected from two cultivation fields. Two fields were selected for the cultivation process with same quality of soil and surroundings, one for conventional method and another one for traditional cultivation method.

\section{Preparation of Semicarpus anacardium manure (3)}

The Semicarpus anacardium (Serankottai) seeds were cut into small pieces and spread in the prepared field and it was covered with sand, which was well irrigated continuously for 3 months until the entire Semicarpus nuts were decomposed with soil.

\section{Plantation of Centella asiatica (Vallarai)}

The seedlings of Centella asiatica (Vallarai) were planted in normal land (Conventional method) and in fertilized land (Traditional method) and irrigated well.

\section{Collection of samples}

After 2 months of planting, the leaves of Centella asiatica (Vallarai) from both lands were collected and dried in room temperature and named as Sample A and Sample B respectively.

\section{Anti-oxidant activity}

The collected samples were subjected to evaluate the anti-oxidant activity by using in-vitro antioxidant assay methods.

\section{DPPH (2, 2-Diphenyl 1-2 picrylhydrazyl) assay: (15)}

The antioxidant activity of test drug samples A and $\mathrm{B}$ were determined using the 2, 2-diphenyl 1-2 picrylhydrazyl (DPPH) free radical scavenging assay method. The test Sample was mixed with $95 \%$ methanol to prepare the stock solution in required concentration. From the stock solution $1 \mathrm{ml}, 2 \mathrm{ml}, 4 \mathrm{ml}, 6 \mathrm{ml} 8 \mathrm{ml}$ and $10 \mathrm{ml}$ of this solution were taken in five test tubes and by serial dilution with same solvent was made the final volume of each test tube up to $10 \mathrm{ml}$ whose concentration is then $10 \mu \mathrm{g} / \mathrm{ml}, 20 \mu \mathrm{g} / \mathrm{ml}, 40 \mu \mathrm{g} / \mathrm{ml}, 60$ $\mu \mathrm{g} / \mathrm{ml}, 80 \mu \mathrm{g} / \mathrm{ml}$ and $100 \mu \mathrm{g} / \mathrm{ml}$ respectively. Ascorbic acid was used as standard and it was prepared in same concentration as that of the sample extract by using methanol as solvent. Final reaction mixture containing 1 $\mathrm{ml}$ of $0.3 \mathrm{mM}$ DPPH methanol solution was added to $2.5 \mathrm{ml}$ of sample solution of different concentrations and it was allowed to react at room temperature. Absorbance in the presence of test sample at different concentrations $(10 \mu \mathrm{g}, 20 \mu \mathrm{g}, 40 \mu \mathrm{g}, 60 \mu \mathrm{g}, 80 \mu \mathrm{g}$ and $100 \mu \mathrm{g} / \mathrm{ml}$ ) were noted after $15 \mathrm{~min}$ incubation period at $37^{\circ} \mathrm{C}$. Absorbance was read out at $517 \mathrm{~nm}$ using doublebeam U.V Spectrophotometer by using methanol as blank.

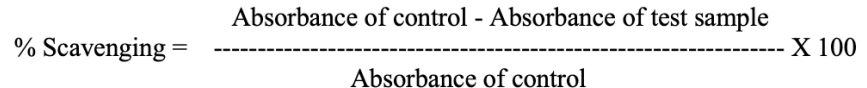

The effective concentration of test samples required to scavenge $\mathrm{DPPH}$ radical by $50 \%$ ( $\mathrm{IC}_{50}$ value) were obtained by linear regression analysis of dose-response curve plotting between $\%$ of inhibition and concentrations.

\section{Nitric Oxide Radical Scavenging Assay: (16)}

The concentrations of test samples were made into serial dilution from $10-100 \mu \mathrm{g} / \mathrm{mL}$ and the standard Gallic acid. Griess reagent was prepared by mixing equal amounts of $1 \%$ sulphanilamide in $2.5 \%$ phosphoric acid and $0.1 \%$ naphthyl ethylenediamine dihydrochloride in $2.5 \%$ phosphoric acid immediately before use. A volume of $0.5 \mathrm{~mL}$ of $10 \mathrm{mM}$ sodium nitroprusside in phosphate buffered saline was mixed with $1 \mathrm{~mL}$ of the different concentrations of the test drugs $(10-100 \mu \mathrm{g} / \mathrm{mL})$ and incubated at $25^{\circ} \mathrm{C}$ for 180 mins. The test drugs were mixed with an equal volume of freshly prepared Griess reagent. Control samples without the test drugs but with an equal volume of buffer was prepared in a similar manner as was done for the test samples. The absorbance measured at $546 \mathrm{~nm}$ using a Spectra Max Plus UV-Vis microplate reader. 
Gallic acid used as the positive control. The percentage of inhibition of the test drugs and standard were calculated and recorded. The percentage of nitrite radical scavenging activity of the test drugs and Gallic acid was calculated by using the following formula:

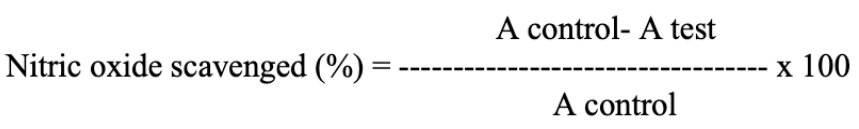

Where A control = absorbance of control sample and A test $=$ absorbance in the presence of the samples extracts of standards.

\section{ABTS Assay: (17)}

This assay carried out for the purpose of evaluating the anti-oxidant potential of test drugs against 2, 2'-azino-bis (3-ethylbenzothiazoline-6sulphonic acid) or ABTS radicals. The ABTS radical cation method was modified to evaluate the free radicalscavenging effect of one hundred pure chemical compounds. The ABTS reagent was prepared by mixing $5 \mathrm{~mL}$ of $7 \mathrm{mM}$ ABTS with $88 \mu \mathrm{L}$ of $140 \mathrm{mM}$ potassium persulfate. The mixture then kept in the dark at room temperature for $16 \mathrm{~h}$ to allow free radical generation and then diluted with water $(1: 44, \mathrm{v} / \mathrm{v})$. To determine the scavenging activity, $100 \mu \mathrm{L}$ ABTS reagent was mixed with $100 \mu \mathrm{L}$ of test sample $(10-100 \mu \mathrm{g} / \mathrm{ml})$ and incubated at room temperature for $6 \mathrm{~min}$. After incubation, the absorbance was measured $734 \mathrm{~nm}$. $100 \%$ methanol was used as a control. Gallic acid with same concentrations of test drugs were measured following the same procedures described above and used as positive controls. The antioxidant activity of the test samples were calculated by using the following equation:

$$
\begin{aligned}
& \text { (A) Control - (A) sample } \\
& \text { Radical scavenging }(\%)= \\
& \text { (A) Control }
\end{aligned}
$$

\section{Hydrogen Peroxide Radical Scavenging Assay: (18)}

A hydrogen peroxide solution $(2 \mathrm{mM})$ was prepared in $50 \mathrm{mM}$ phosphate buffer ( $\mathrm{pH} 7.4)$. Aliquots $(0.1 \mathrm{~mL})$ of the test sample $\mathrm{A}$ and $\mathrm{B}$ (different concentration ranging from $10-100 \mu \mathrm{g} / \mathrm{ml}$ ) were transferred into the test tubes and their volumes were made up to $0.4 \mathrm{~mL}$ with $50 \mathrm{mM}$ phosphate buffer $(\mathrm{pH}$ 7.4). After adding $0.6 \mathrm{~mL}$ hydrogen peroxide solution, tubes were vortexed and the absorbance of the hydrogen peroxide at $230 \mathrm{~nm}$ was determined after $10 \mathrm{~min}$, against a blank. Butylated hydroxyanisole (BHA) was used as the positive control. The percentage of inhibition of the test sample A, B and standard were calculated and recorded. The percentage radical scavenging activity of the test sample A and B and BHA was calculated by using the following formula:

$$
\text { Radical scavenging }(\%)=\frac{\text { (A) Control - (A) sample }}{------a) \text { Control }}
$$

\section{Results and Discussion}

In DPPH radical scavenging assay, the trial drugs sample - A and sample - B showed that the percentage of inhibition ranges from $7.746 \pm$ 1.797 to $53.79 \pm 3.626$ for sample A and $16.47 \pm$ 2.983 to $74.7 \pm 1.731 \%$ for sample $\mathrm{B}$ when compared with standard drug Ascorbic acid with percentage of inhibition ranges from $45.28 \pm$ 3.244 to $97.08 \pm 1.24 \%$. The $\mathrm{IC}_{50}$ value of the trial drug was $88.6 \pm 8.536(\mu \mathrm{g} / \mathrm{ml})$ for sample A and $57.06 \pm 1.221(\mu \mathrm{g} / \mathrm{ml})$ for sample B when compared with standard drug ascorbic acid with $\mathrm{IC}_{50}$ value $15.13 \pm 2.464 \mu \mathrm{g} / \mathrm{ml}$. Sample B shows higher DPPH radical scavenging activity than sample A.

\section{Figure 1: DPPH radical scavenging activity of Centella asiatica}

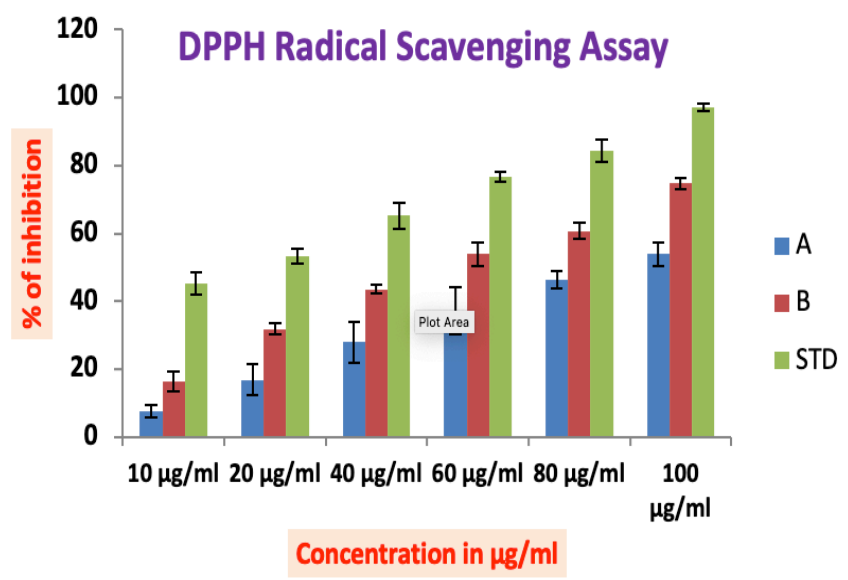

Table 1: IC $_{50}$ Values for DPPH radical scavenging activity of Centella asiatica

Test Drug / Standard IC 50 Value DPPH Assay \pm $\mathrm{SD}(\mu \mathrm{g} / \mathrm{ml})$

Ascorbic acid

$15.13 \pm 2.464$

Sample A

$88.6 \pm 8.536$

Sample B $57.06 \pm 1.221$

Data are given as Mean \pm SD $(n=3)$

In Nitric Oxide radical scavenging assay, the result revealed that the percentage of inhibition of the test drugs sample - A and ample - B ranges from $7.971 \pm 4.641$ to $30.46 \pm 1.885$ for sample A and $17.07 \pm 3.84$ to $39.26 \pm 0.8682 \%$ for sample B when compared with standard drug Gallic acid with percentage of inhibition ranges from $44.22 \pm$ 8.589 to $97.76 \pm 0.7092 \%$. The $\mathrm{IC}_{50}$ value of the trial drug was $183 \pm 15.55(\mu \mathrm{g} / \mathrm{ml})$ for sample A and $145.1 \pm 13.12(\mu \mathrm{g} / \mathrm{ml})$ for sample $B$ when compared with standard drug Gallic acid with $\mathrm{IC}_{50}$ value $12.85 \pm 10.36 \mu \mathrm{g} / \mathrm{ml}$. On comparing both $\mathrm{IC}_{50}$ values, Sample $\mathrm{B}$ has effective radical scavenging activity than sample A. 
Figure 2: Nitric Oxide Radical Scavenging activity of Centella asiatica

Nitric Oxide Radical Scavenging Assay

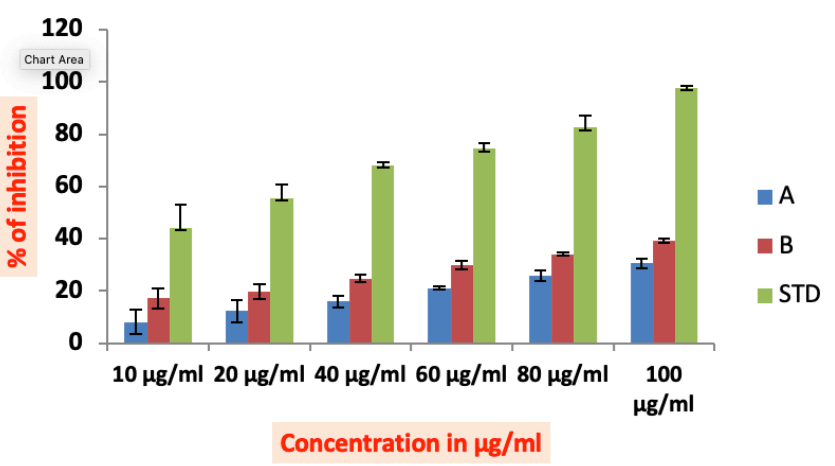

Table 2: IC $_{50}$ Values for Nitric Oxide radical scavenging activity of Centella asiatica

\begin{tabular}{l|c|}
\multicolumn{1}{c|}{ Test Drug / Standard } & $\begin{array}{c}\text { IC }_{50} \text { Value NO Assay } \\
\pm \mathrm{SD}(\mu \mathrm{g} / \mathrm{ml})\end{array}$ \\
\hline Gallic acid & $12.85 \pm 10.36$ \\
Sample A & $183 \pm 15.55$ \\
Sample B & $145.1 \pm 13.12$ \\
Data are given as Mean $\pm \mathrm{SD}(\mathrm{n}=3)$
\end{tabular}

In Hydrogen peroxide radical scavenging assay, the trial drugs sample - A and sample - B showed that the percentage of inhibition ranges from $2.94 \pm 0.5557$ to $27.03 \pm 2.569$ for sample A and $9.888 \pm 2.34$ to $39.59 \pm 4.583 \%$ for sample B when compared with standard BHA with percentage of inhibition ranges from $33.39 \pm 2.94$ to $90.68 \pm 4.421 \%$. The $\mathrm{IC}_{50}$ value of the trial drug was $183 \pm 11.64(\mu \mathrm{g} / \mathrm{ml})$ for sample A and $132.3 \pm 18.71(\mu \mathrm{g} / \mathrm{ml})$ for sample B when compared with standard BHA with $\mathrm{IC}_{50}$ value $38.03 \pm 1.634 \mu \mathrm{g} /$ $\mathrm{ml}$. The results revealed that the sample B shows higher Hydrogen peroxide radical scavenging activity than sample A.

Fig.no:3. Hydrogen peroxide radical scavenging activity of Centella asiatica

Hydrogen peroxide Radical Scavenging Assay

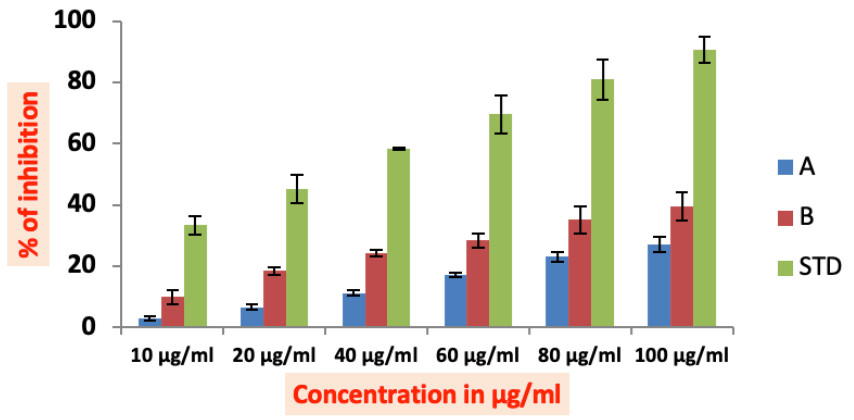

Table 3: IC $_{50}$ Values for Hydrogen peroxide radical scavenging activity of Centella asiatica

Test Drug / IC $\quad$ IC $_{50}$ Value Hydrogen peroxide radical Standard $\quad$ scavenging Assay \pm SD $(\mu \mathrm{g} / \mathrm{ml})$

Sample A $\quad 183 \pm 11.64$

Sample B $\quad 132.3 \pm 18.71$

BHA $\quad 38.03 \pm 1.634$

Data are given as Mean $\pm \mathrm{SD}(\mathrm{n}=3)$
In ABTS radical scavenging assay, the trial drugs sample - A and Sample - B showed that the percentage of inhibition ranges from $14.2 \pm 0.3889$ to $54.16 \pm 7.832$ for sample A and $3.259 \pm 0.974$ to $49.32 \pm 1.317 \%$ for sample B when compared with standard drug Gallic acid with percentage of inhibition ranges from $31.32 \pm 3.909$ to $96.39 \pm 1.535 \%$. The $\mathrm{IC}_{50}$ value of the trial drug was $78.92 \pm 8.43(\mu \mathrm{g} / \mathrm{ml})$ for sample A and $96.45 \pm 3.966(\mu \mathrm{g} / \mathrm{ml})$ for sample B when compared with standard drug Gallic acid with $\mathrm{IC}_{50}$ value $24.25 \pm 3.571 \mu \mathrm{g} / \mathrm{ml}$. The results revealed that the sample A possess higher ABTS radical scavenging activity than sample B.

\section{Fig. No: 4. ABTS radical scavenging activity of Centella asiatica}

ABTS Radical Scavenging Assay

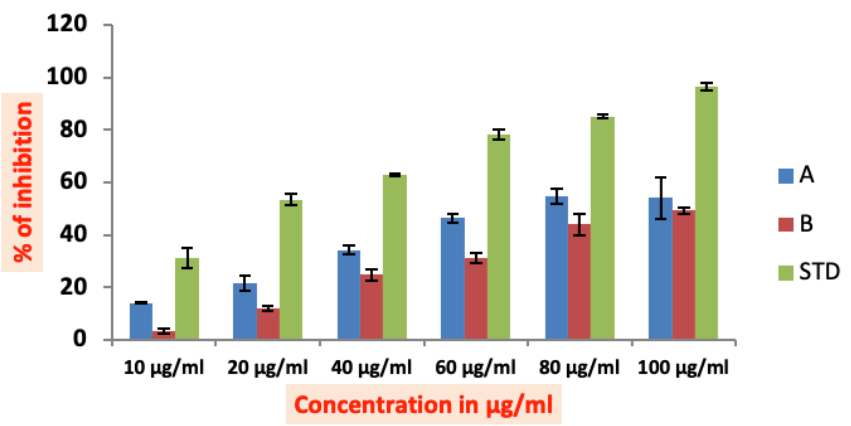

Table 4: IC I0 $_{0}$ Values for ABTS radical scavenging activity of Centella asiatica

\begin{tabular}{|c|c|}
\hline Test Drug / Standard & $\begin{array}{c}\mathbf{I C}_{\mathbf{5 0}} \text { Value ABTS Assay } \\
\mathbf{\mathbf { ~ S D }}(\boldsymbol{\mu g} / \mathbf{m l})\end{array}$ \\
\hline Sample A & $78.92 \pm 8.43$ \\
\hline Sample B & $96.45 \pm 3.966$ \\
\hline Gallic acid & $24.25 \pm 3.571$ \\
\hline
\end{tabular}

Data are given as Mean \pm SD $(n=3)$

\section{Conclusion}

The In-vitro anti-oxidant activities were studied for Centella asiatica sample A - (cultivated by conventional method) and sample B (cultivated by traditional method). This study results revealed that the both samples of Centella asiatica possess good antioxidant property but sample B exhibited higher scavenging activity when compared to sample A. The outcome of the study may helps to cultivate the medicinal herbs by traditional cultivation method for rejuvenation purpose. This cultivation method can be adopted for conservation of endangered herbs also, which helps to retain the active components. This is a preliminary study and further studies will be carried out to explore the value and importance of traditional cultivation methods.

\section{Acknowledgements}

The authors acknowledge with thanks for the support provided by the National Institute of Siddha to carry out this preliminary research work. 


\section{References}

1. Camps J, García-Heredia A. Introduction: oxidation and inflammation, a molecular link between noncommunicable diseases. Adv Exp Med Biol. 2014;824: 1-4.

2. Thiyagarajan R. Siddha Maruthuvam Sirappu. 1st ed. Directorate of Indian Medicine and Homeopathy; Chennai-106;2013. $3-7 \mathrm{p}$.

3. Hakim P.Muhammad Abdullah Sahibu. Kadukkai vallarayin thani maanbu. $1^{\text {st }}$ ed. Directorate of Indian Medicine and Homeopathy; Chennai-106; 1992. 89p.

4. Lester Mandelker. Introduction to Oxidative Stress and Mitochondrial Dysfunction. Veterinary Clinics of North America. Small Animal Practice. Volume 38; Issue 1,2008; 1-30.

5. Lobo V, Patil A, Phatak A, Chandra N. Free radicals, antioxidants and functional foods: Impact on human health. Pharmacogn Rev. 2010;4(8); 118-126.

6. Murugesa Mudhaliyar K.C. Siddha Materia Medica (Medicinal Plants Division). 2nd ed. Directorate of Indian Medicine and Homeopathy, Chennai-106. 2008. $792-794$ p.

7. CABI. Centella asiatica [original text by Chris Parker]. In: Parker C. Invasive Species Compendium. Available at https://www.cabi.org/isc/ datasheet/ 12048. Accessed September 13, 2019.

8. Indian herbal Pharmacopeia. Revised new edition. Published by Indian Drug Manufacturers Association; Mumbai-400018. 2002.

9. Kuppusamy Mudhaliar K.N, Uththamarayan K.S. Siddha Vaidya Thirattu. $1^{\text {st }}$ ed. Directorate of Indian Medicine and Homeopathy, Chennai-106; 2014. 252 - 255p.

10. Sharma P.C, Yelne M.B, Dennis T.J et al. Data base on medicinal plants used in Ayurveda. Central council for research in Ayurveda \& Siddha, Janakpuri, New Delhi. 2000. Vol (1); Page no. 469-471.
11. Razali NNM, Ng CT, Fong LY. Cardiovascular Protective Effects of Centella asiatica and Its Triterpenes: A Review. Planta Med. 2019 Nov;85(16):1203-1215.

12. Gray NE, Alcazar Magana A, Lak P, Wright KM, Quinn J, Stevens JF, Maier CS, Soumyanath A. Centella asiatica - Phytochemistry and mechanisms of neuroprotection and cognitive enhancement. Phytochem Rev. 2018 Feb;17(1):161-194.

13. Kabir AU, Samad MB, D'Costa NM, Akhter F, Ahmed A, Hannan JM. Anti-hyperglycemic activity of Centella asiatica is partly mediated by carbohydrase inhibition and glucose-fiber binding. BMC Complement Altern Med. 2014 Jan 18; 14-31.

14. Naidoo DB, Chuturgoon AA, Phulukdaree A, Guruprasad KP, Satyamoorthy K, Sewram V. Centella asiatica modulates cancer cachexia associated inflammatory cytokines and cell death in leukaemic THP-1 cells and peripheral blood mononuclear cells (PBMC's). BMC Complement Altern Med. 2017 Aug 1;17(1):377.

15. Liyana- Pathiranan, C.M and Shadidi F. Antioxidant activity of commercial soft and hard wheat (Triticum aestivum L.) as affected by gastric $\mathrm{Ph}$ conditions. J. Agric. Food Chem. 2005. 53: 2433-2440.

16. Rozina Parul et.al. In Vitro Nitric Oxide Scavenging Activity of Methanol Extracts of Three Bangladeshi Medicinal Plants. The Pharma Innovation - Journal; 2013; Vol. 1(12).

17. Re R., Pellegrini N, Proteggente A, Pannala A, M. Yang and C. Rice- Evans. Antioxidant activity applying an improved ABTS radical cation decolorization assay. Free Radic. Biol. Med. 1999. 26: 1231-12.

18. Ruch R. J., Cheng S.J, Klaunig J. E. Prevention of cytotoxicity and inhibition of intercellular communication by antioxidant catechins isolated from Chinese green tea. Carcinogenesis. 1989; 10(6):1003-1008. 